\title{
Which Came First, the Chicken or the Egg? Banks and Firms on Local Banking Markets*
}

\author{
Krzysztof JACKOWICZ—Kozminski University, Warsaw (krzysztof.jackowicz@onet.eu), \\ corresponding author \\ Łukasz KOZŁOWSKI—Kozminski University, Warsaw
}

\section{Abstract}

This study investigates the interactions between the financial health of cooperative banks and the performance of small and medium-sized enterprises (SMEs). Using a unique dataset on local banking markets in Poland, we establish that a strong financial standing of SMEs improves the profitability of banks that operate in the same neighborhood; however, the growth of banks is not affected. In contrast, the financial situation of cooperative banks is generally irrelevant for SME performance.

\section{Introduction}

In this paper, we attempt to establish how the financial strength of banks and the standing of non-financial firms interact. To elucidate this interesting and important topic, we use a methodology based on local banking markets. We analyze whether cooperative banks' fundamentals influence small and medium-sized enterprises' performance; we also study the extent to which cooperative banks' results are determined by the financial strength of their potential clients.

Because of the geocoding of firms and banks' branches, we are able to define local banking markets by applying different radiuses from a bank branch or a firm's headquarters. Using information on local banking markets, we estimate a static panel model explaining, on the one hand, cooperative banks' performance and, on the other hand, SMEs' financial standing. In each model we include firm- and bank-level control variables along with control variables reflecting local economic and competitive conditions. Our sample covers the period from 2007 to 2013. In our investigation we combine four data sources: financial statements of cooperative banks in Poland, addresses and financial statements of SMEs, a database of all bank branches' addresses, and official statistical information concerning the economic situation in different counties.

In general terms, we find that, as expected, the strong financial standing of local SMEs positively and significantly impacts the various aspects of cooperative banks' performance and activities. However, the inverse relation is almost nonexistent. In other words, we fail to demonstrate that strong local banks boost SMEs' results. Moreover, we establish that the positive impact of SMEs' standing on cooperative banks weakens during difficult economic times.

The remainder of this paper is organized as follows: Section 2 briefly reviews the relevant literature and presents our hypotheses. Section 3 describes our method-

\footnotetext{
* The authors acknowledge the financial support of the National Science Center, Poland (NCN), project no. 2014/13/B/HS4/00209, contract number UMO-2014/13/B/HS4/00209, pt. "Wpływ lokalnych struktur rynku bankowego na finansowanie małych i średnich przedsiębiorstw".
} 
ological approach and data sources. Section 4 contains empirical results and their interpretation. In Section 5, we summarize our findings.

\section{Brief Literature Review and Hypotheses}

The existing literature addressing the relationships between banks and SMEs concentrates mainly on the influence of those relationships on firms. The impact in the opposite direction is nearly ignored. To the best of our knowledge, a recent study by Fredriksson and Moro (2014) constitutes the notable exception to this rule. Using Finnish data, the authors find that the quality of SMEs performance strongly affects the risk-adjusted profitability of small banks.

In contrast, the role of bank lending in shaping SMEs' performance has been studied by hundreds of authors. The majority of studies conclude that relationships with local, cooperative or community banks are beneficial for SMEs. DeYoung (2002) argues that community banks have a comparative advantage over larger banks in relationship banking. Petersen and Rajan (1994) show that the smallest firms tend to concentrate their borrowing at a single bank with which they have a long-term relationship. De Haas et al. (2010) report that small banks lend more often to SMEs than do large banks in post-transition countries. Moreover, Presbitero et al. (2014) documented that, in Italy, the credit crunch during the recent crisis was more pronounced in provinces that had a large share of bank branches owned by distantly managed organizations. However, the advantage of small banks in lending to SMEs is conditional on several factors. For example, Zhang et al. (2015) demonstrate that small banks are only superior in granting loans to SMEs through a pre-existing relationship, whereas Berger et al. (2015) show that a greater market presence of small banks results in more lending to start-up firms only during non-crisis periods in the US.

The privileged lending relationships between local banks and SMEs do matter for SMEs. This type of lending tends to ease the financial constraints encountered by SMEs. Behr et al. (2013) find that an increase in relative borrowings from local stateowned banks significantly reduces financial constraints. In turn, Ryan et al. (2014) establish that increased market power of banks results in higher financial constraints for SMEs. Additionally, Abor et al. (2014) find that access to bank loans improves the likelihood of SMEs to export.

Close relationships between local banks and SMEs facilitate monitoring and help to overcome problems of asymmetric information (Boot, 2000). Access to private, soft information and the ability to influence firms' decisions enable banks engaged in relationship banking to remain with their customers when they encounter serious financial difficulties. In line with these theoretical expectations, Höwer (2000) shows that small banks in Germany serve a greater share of improved firms and a lower share of closed firms. Moreover, relationship banking leaves room for flexibility in contracting, facilitates asset-based lending when close monitoring is needed and allows for assessment of loan profitability over the long term (Boot, 2000). Borrower and lender proximity, as Agarwal and Hauswald (2010) showed, facilitates the collection of subjective firm-specific intelligence.

Relationship banking also has a dark side. First, banks involved in long-term relationships with their clients are more likely to keep distressed firms alive; there- 
fore, a soft budget constraint problem may arise (Peek and Rosengren, 2005). Second, long-term lending may give a bank a quasi information monopoly and create the so-called hold-up problem (Boot, 2000). Indeed, Berger et al. (2005) and Uchida et al. (2008) found that small banks tend to have longer-term and more exclusive relationships with firms.

Considering the existing empirical evidence and the fact that our investigation concerns an emerging economy where the role of soft information in contracting is more important than in developed countries, we expect that positive feedback between cooperative banks' condition and SMEs' performance exists. Therefore, we test two hypotheses.

H1: A strong financial standing of SMEs improves performance and boosts the growth of cooperative banks operating in the same neighborhood.

H2: Financially strong cooperative banks facilitate SMEs' development and positively influence their economic results.

As we have already mentioned, soft information plays a primordial role in relationship banking that involves cooperative banks and SMEs. However, the role of this kind of information may vary with the business cycle. We conjecture that reciprocal benefits of relationship banking should be more important during difficult economic times when soft information tells more about firms' prospects than do current financial statements and when the reduction of information asymmetry is more valuable. Therefore, we formulate our third and final hypothesis.

H3: The positive feedback between SMEs' performance and cooperative banks' financial health is more pronounced during economic downturns.

\section{Methodology and Data}

\subsection{Basic Approach}

Figure 1 presents our basic methodological approach. To study the influence of an SME's financial health on cooperative banks' performance, we identify all SMEs that are located within $2.5 \mathrm{~km}$ and $5 \mathrm{~km}$ radiuses from a given bank's branches. We then calculate the average values of selected financial ratios for SMEs that are located within those radiuses. To test the inverse relation, we apply a slightly different procedure. Namely, we identify SMEs that solely have branches of banks that belong to the BPS (Bank Polskiej Spółdzielczości) association within a $2.5 \mathrm{~km}$ and $5 \mathrm{~km}$ radius from their headquarters. ${ }^{1}$ By selecting a banking market that is populated by one association of cooperative banks, we reduce the sample size; however, at the same time, and more importantly, we increase the chances that our empirical results will reflect the real economic impact of local banks' financial strength on local firms' performance and activities.

\subsection{Models and Variables}

Formally, to test the influence of SMEs' financial health on cooperative banks' performance, we estimate static panel models with random effects. We prefer this method over the fixed-effects estimator as our baseline method because the explana-

1 The financial data for cooperative banks that belong to the other association-Spółdzielcza Grupa Bankowa - are unavailable. 


\section{Figure 1 Banks and SMEs on Local Banking Markets Main Methodological Approach}

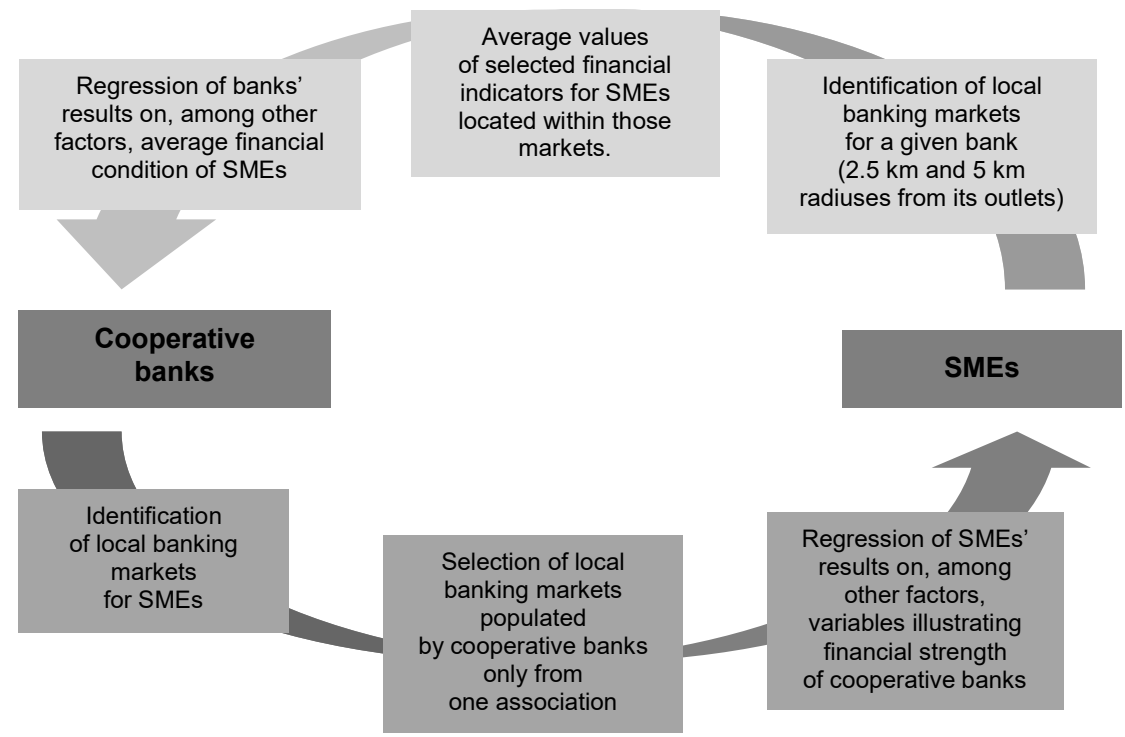

tory variables describing the local environment are relatively stable over time for each bank and firm. Thus, adding fixed effects raises some concerns about potential multicollinearity of variables as the linear combination of fixed effects could be correlated with any of the variables reflecting the banks' and firms' local environment. The general construction of our models is illustrated by equation (1):

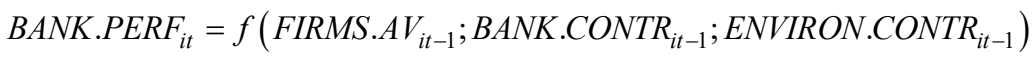

where $B A N K . P E R F_{i t}$ is a group of dependent variables that are used interchangeably to illustrate the performance of cooperative bank $i$ in period $t$. We selected eight dependent variables that are related to three aspects of cooperative banks' functioning. Namely, we study the determinants of cooperative banks' profitability (the variables NIM, OROA and ROA), asset quality (the variable ASSETS.Q) and growth (the variables ASSETS.GR, LOANS.GR and DEPOSITS.GR).

The set of explanatory variables consists of three groups of variables. The first group, FIRMS.AV $V_{i t}$, is designed to test hypothesis 1 . This group includes lagged variables that reflect the financial characteristics of SMEs operating within the local banking market, such as the following: investment activity (variable $A V G . I N V E S T$ ), scale of operations (variable $A V G . L N S$ ), stock of liquid assets (variable $A V G . C A S H$ ), structure of liabilities (variable $A V G$.LT.LIAB), sales profitability (variable $A V G . E B I T . S$ ), asset turnover (variable $A V G . T A T$ ) and the dynamics of profits (variable AVG.EBIT.GR). The values of the variables from the group FIRMS.AV are calculated as averages for the SMEs located within $2.5 \mathrm{~km}$ and $5 \mathrm{~km}$ radiuses from the given bank branches.

The second (BANK.CONTR $\left.{ }_{i t}\right)$ and the third (ENVIRON.CONTR $\left.{ }_{i t}\right)$ groups of independent variables control for the bank level and are related to local economic conditions and the potential determinants of cooperative banks' performance, respec- 
tively. In the group of bank-level control variables, we include lagged financial ratios that illustrate the capital base (variable EQUITY), the share of loans in total assets (variable $L O A N S$ ), scale of operations (variable $L N A$ ), the dominant component of activities (variable FEES) and the level of operational costs (variable OVERHEADS). The variables from the ENVIRON.CONTR group describe economic situations in counties where cooperative banks are domiciled. The variables reflect the level of population income (variable $S A L A R Y$ ), the economic activity of the population (variable ENTREPREN), the level of unemployment (variable UNEMPL), the density of the population (variable POPUL.DENS) and the strength of competition in local banking markets (variable COMPETITORS).

Detailed definitions of all dependent and explanatory variables used in equation (1) are presented in Table 1. The correlation matrices for all variables are available from the authors upon request.

To test hypothesis 2 concerning the impact of cooperative banks' health on SMEs' performance, we also estimate static panel models with random effects. Equation (2) illustrates the general construction of those models.

$S M E . P E R F_{k t}=f\left(B A N K . A V_{k t-1} ; F^{2}\right.$ IRM.CONTR ${ }_{k t-1} ;$ ENVIRON.CONTR $_{k t-1} ;$ INDUSTRY $\left._{l}\right)$

In equation (2), SME.PERF $F_{k t}$ signifies a group of dependent variables that illustrate the performance, growth and activities of small firm $k$ in period $t$. Namely, we use two measures of profitability as dependent variables (EBIT.S and GROSS.PR.S), the share of long-term liabilities in total liabilities (LT.LIAB), investment intensity (INVEST) and sales growth (SALES.GR).

The set of explanatory variables can be divided into four groups. The first, $B A N K . A V_{k t-1}$, serves as a tool to test hypothesis 2 because it describes the average financial health of a cooperative bank within a $2.5 \mathrm{~km}$ or $5 \mathrm{~km}$ radius from an SME's headquarters. This group includes lagged variables (by one period) that reflect the capital base (EQUITY), profitability (ROA) and asset quality (ASSETS.Q). The second group, $F_{\text {FIRM.CONTR }}$, reflects potentially important lagged, firm-level drivers of SMEs' performance and activities, such as the following: the scale of operations (variable $L N S$ ), asset turnover (variable $T A T$ ), stock of liquid assets (variable $C A S H$ ), the intensity of investment activity (variable INVEST), the share of fixed assets in total assets (variable $F I X A$ ) and profitability (variable EBIT.S). The last two variables are excluded when profitability measures or investment activity ratios are used as dependent variables, respectively. The third group, as in the case of equation (1), describes the traits of a local economic environment (variables SALARY, ENTREPRENEURS, UNEMPL and POPUL.DENS). Additionally, in equation (2), we introduce industry dummies (INDUSTRY $Y_{1}$ ) because the influence of certain firm-level variables may be strongly industry-sensitive.

To check whether the macroeconomic tendencies influence the positive feedback between cooperative banks' health and SMEs' performance, we introduce the binary variable DOWNTURN. This variable takes the value of one for the years 2009, 2012 and 2013 when the dynamics of GDP growth were the lowest during the sample period. It is worth stressing that the slowdown years in Poland do not correspond to the period of the recent global financial crisis. The Polish economy recorded more than respectable $7.16 \%$ and 3.87\% GDP growth in 2007 and 2008, 
Table 1 Dependent and Explanatory Variables

\section{A: Variables related to individual cooperative banks' performance and activities}

\begin{tabular}{|c|c|}
\hline Variable name & Variable definition \\
\hline ROA, OROA & Return and operating return on average assets, respectively \\
\hline EQUITY & Ratio of equity to total assets \\
\hline LOANS & Ratio of loans to total assets \\
\hline LNA & Natural logarithm of total assets in constant prices \\
\hline FEES & Ratio of net fee and commission income to operating income \\
\hline OVERHEADS & Ratio of overheads to operating income \\
\hline ASSETS.Q & $\begin{array}{l}\text { Ratio of yearly net loan loss provisions multiplied by }(-1) \\
\text { and average loans }\end{array}$ \\
\hline NIM & Ratio of net interest income to average assets \\
\hline $\begin{array}{l}\text { ASSETS.GR, LOANS.GR, } \\
\text { DEPOSITS.GR }\end{array}$ & $\begin{array}{l}\text { Yearly growth rates (in constant prices) of assets, loans } \\
\text { and deposits, respectively }\end{array}$ \\
\hline
\end{tabular}

B: Variables related to individual SMEs' performance and activities

\begin{tabular}{l|l}
\hline Variable name & Variable definition \\
\hline EBIT.S & Operating profit/loss to sales \\
GROSS.PR.S & $\begin{array}{l}\text { Gross profit/loss to sales } \\
\text { Ratio of non-current liabilities to total liabilities }\end{array}$ \\
LT.LIAB & Growth rate of tangible fixed assets in constant prices \\
INVEST & Growth rate of sales in constant prices \\
SALES.GR & Natural logarithm of sales in constant prices \\
LNS & Ratio of sales to total assets \\
TAT & Ratio of cash and cash equivalent to total assets \\
CASH & Ratio of fixed assets to total assets \\
FIXA &
\end{tabular}

C: Explanatory variables illustrating average financial condition of SMEs' operating in a bank's neighbourhood*

\begin{tabular}{l|l}
\hline Variable name & Variable definition \\
\hline AVG.INVEST & $\begin{array}{l}\text { Growth rate of tangible fixed assets in constant prices } \\
\text { Natural logarithm of sales in constant prices }\end{array}$ \\
AVG.LNS & $\begin{array}{l}\text { Ratio of cash and cash equivalent to total assets } \\
\text { Ratio of long-term liabilities to total liabilities }\end{array}$ \\
AVG.CASH & $\begin{array}{l}\text { Operating profit/loss to sales } \\
\text { AVG.LT.LIAB }\end{array}$ \\
AVG.EBIT.S & $\begin{array}{l}\text { Ratio of sales to total assets } \\
\text { in constant prices }\end{array}$ \\
\hline AVG.TAT & AVG.EBIT.GR
\end{tabular}

Notes: * For each bank branch, we calculated the average measures of the financial condition of SMEs located within a given radius from a bank branch $(2.5 \mathrm{~km}$ or $5 \mathrm{~km}$, depending on the model specification). For all measures, except for AVG.LNS, these were weighted averages with weights equal to the natural logarithms of individual SMEs' sales. Finally, to reflect a 'general' condition of SMEs that operate in the neighbourhood of all bank branches, we calculated the median values obtained for this bank's branches. 
D: Explanatory variables reflecting average financial condition of banks operating in an SME's neighbourhood*

\begin{tabular}{|c|c|}
\hline Variable name & Variable definition \\
\hline AVG.ROA & Return and operating return on average assets \\
\hline AVG.EQUITY & Equity to total assets \\
\hline AVG.ASSETS.Q & $\begin{array}{l}\text { Ratio of yearly net loan loss provisions multiplied by }(-1) \text { and } \\
\text { average loans }\end{array}$ \\
\hline
\end{tabular}

\section{E: Explanatory variables illustrating local economic situation}

\begin{tabular}{l|l}
\hline Variable name & Variable definition \\
\hline SALARY & $\begin{array}{l}\text { Ratio of average salary in a county to a country's average } \\
\text { County-level ratio of self-employed entrepreneurs and working } \\
\text { age population } \\
\text { Unemployment rate in a county }\end{array}$ \\
\hline ENTREPREN & $\begin{array}{l}\text { County-level population density (in thousands } / \mathrm{km}^{2} \text { ) } \\
\text { A number of other banks' and credit unions' branches within the } \\
\text { radius of } 2.5 / 5 \mathrm{~km} \text { (a median for a bank's branches) }\end{array}$ \\
\hline POPUL.DENS & COMPETITORS
\end{tabular}

Notes: * In different model specifications, we use different radiuses.

respectively. To test hypothesis 3, we interact the variable $D O W N T U R N$ with the variables from the group FIRMS.AV $V_{i t}$ in equation (1) and with the variables from the group $B A N K . A V_{k t-1}$ in equation (2).

In the econometric investigations, there is always a possibility that accidental associations are mistakenly taken for causal relations. We believe that two elements of our empirical strategy serve as a hedge against such undesirable outcomes. First, all our regressors are lagged by one period. Second, in both equations (1) and (2), we simultaneously include bank-level, firm-level and county-level variables. Therefore, we control for a broad range of potential determinants of the studied phenomena. Moreover, as a robustness check, we have re-estimated equation (1) with bank-fixed effects and equation (2) with firm-fixed effects. Consequently, we gained a greater degree of certainty that our results are not driven by the directly unobserved but are stable in the time traits of banks and firms.

Because standard errors are likely to be correlated for each entity (i.e., a bank or a firm), we additionally use clustered standard errors to evaluate the statistical significance of the estimated coefficients in equations (1) and (2). Failure to do so could understate the standard errors, inflate the test statistics and, consequently, decrease the $p$-values that lead to an unjustifiable rejection of the null hypothesis that a coefficient is equal to zero.

\subsection{Data}

To estimate equations (1) and (2), we combined four data sources. The first source consists of financial statements from 364 cooperative banks associated within the BPS group (Bank Polskiej Spółdzielczości S.A.). The information covers the 2007-2013 period and almost two-thirds of all cooperative banks in Poland. ${ }^{2}$ As Figure 2 
Figure 2 Branch Locations of the Analysed Banks

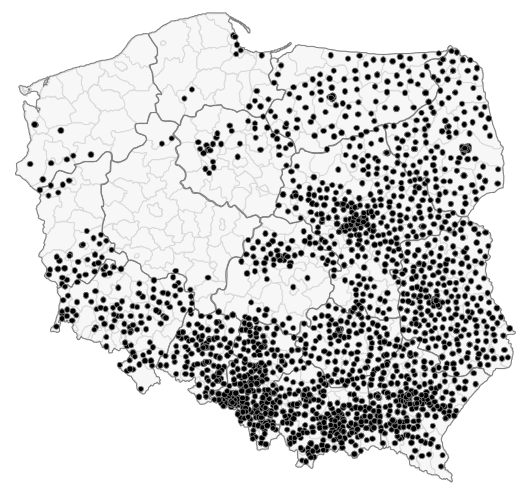

shows, the banks are located in many regions of Poland with the exception of the northwestern part of the country. Although they operate mostly in small towns or rural areas, a significant share of their branches is also located in big cities like Warsaw, Krakow, Katowice or Wrocław. The second dataset is composed of the addresses of all bank and credit union (SKOK-i) branches in Poland in 2007-2013; these were provided by an independent consulting company, Inteliace Research. The third dataset covers the financial statements and addresses of Polish SMEs for the 2006-2012 period and originates from the Amadeus database provided by Bureau van Dijk. We identified SMEs in accordance with the definition of the European Commission, which is also used by Eurostat; according to this definition, SMEs employ fewer than 250 persons and have annual turnover of not more than EUR 50 million or a balance sheet total of not more than EUR 43 million. We excluded companies that did not meet those criteria in at least one year during the 2006-2012 period. In addition, we restricted our sample to companies from sections A-C and F-I of the NACE Rev. 2 industry classification, which means that we excluded the following: financial institutions; utilities; industries dominated by the public sector; professional, scientific, technical and administrative activities; and other industries that usually do not rely on bank loans as an important source of financing (Hasan et al., 2015). Based on the addresses of SMEs and credit institution branches, we found their latitudes and longitudes and finally calculated the distances between each pair. In further steps, this activity allowed us to analyze the performance of SMEs that operate within a given area around a cooperative bank branch, as well as to analyze the financial standing of cooperative banks as a function of the condition of SMEs located in their nearest neighborhood. Finally, our fourth dataset consists of county-specific information provided by the Polish Central Statistical Office. In models that explain bank performance for each bank and each year, we calculated the weighted averages of county-level variables with weights equal to the share of the given bank's branches in individual counties. Conversely, in regressions for SMEs' financial condition the adequate values for the county where a SME was domiciled were assigned to each company. Table 2 presents the descriptive statistics for our final database.

${ }^{2}$ At the end of 2013, there were 571 cooperative banks, including one unassociated bank and 570 banks from two associations, i.e., BPS and SGB. 
Table 2 Descriptive Statistics

\begin{tabular}{lcccccc}
\hline A: Information on cooperative banks & & & & & \\
Variable & $\begin{array}{c}\text { Observa- } \\
\text { tions }\end{array}$ & Mean & Median & $\begin{array}{c}\text { Std. } \\
\text { deviation }\end{array}$ & Minimum & Maximum \\
\hline ROA & 2492 & 0.0125 & 0.0118 & 0.0070 & -0.0549 & 0.0472 \\
OROA & 2492 & 0.0159 & 0.0149 & 0.0083 & -0.0553 & 0.0589 \\
EQUITY & 2858 & 0.1336 & 0.1234 & 0.0499 & 0.0085 & 0.4147 \\
LNA & 2498 & 18.0109 & 17.9378 & 0.8432 & 15.8990 & 21.6232 \\
FEES & 2848 & 0.2567 & 0.2523 & 0.0660 & -0.0255 & 0.5886 \\
OVERHEADS & 2858 & Q0.6538 & 0.6593 & 0.0985 & 0.3420 & 1.3102 \\
ASSETS.Q & 2415 & -0.0023 & -0.0006 & 0.0061 & -0.0860 & 0.0098 \\
NIM & 2492 & 0.0441 & 0.0431 & 0.0099 & 0.0213 & 0.0880 \\
ASSETS.GR & 2132 & 0.0778 & 0.0729 & 0.0932 & -0.4092 & 0.9539 \\
\hline LOANS.GR & 2116 & 0.0972 & 0.0777 & 0.1580 & -0.4834 & 1.1946 \\
DEPOSITS.GR & 2036 & 0.0725 & 0.0733 & 0.0910 & -0.4468 & 0.2999 \\
\hline COMPETITORS* & 2903 & 8.3558 & 2.0000 & 17.2054 & 0.0000 & 171.0000 \\
\hline
\end{tabular}

Note: * within a $5 \mathrm{~km}$ radius (a median for a bank's branches)

B: Information on SMEs located in areas served only by cooperative banks from the BPS association*

\begin{tabular}{lcccccc}
\hline Variable & $\begin{array}{c}\text { Observa- } \\
\text { tions }\end{array}$ & Mean & Median & $\begin{array}{c}\text { Std. } \\
\text { deviation }\end{array}$ & Minimum & Maximum \\
\hline EBIT.S & 8683 & 0.0424 & 0.0289 & 0.1872 & -2.0000 & 0.9777 \\
GROSS.PR.S & 8669 & 0.0360 & 0.0221 & 0.1882 & -1.9286 & 1.0000 \\
LT.LIAB & 9030 & 0.0814 & 0.0011 & 0.1495 & 0.0000 & 0.9979 \\
INVEST & 7688 & 0.0364 & -0.0008 & 0.1621 & -0.9718 & 1.1880 \\
SALES.GR & 7516 & 0.0510 & 0.0082 & 0.3699 & -0.9999 & 2.9256 \\
LNS & 8845 & 10.6177 & 10.7513 & 1.6454 & 2.0764 & 15.8132 \\
TAT & 8634 & 2.6545 & 2.0582 & 2.0952 & 0.0001 & 10.0000 \\
CASH & 8560 & 0.1223 & 0.0545 & 0.1735 & 0.0000 & 1.0000 \\
FIXA & 9088 & 0.4093 & 0.4145 & 0.2620 & 0.0000 & 1.0000 \\
\hline
\end{tabular}

Note: * Only cooperative banks from the BPS association have branches within a $5 \mathrm{~km}$ radius from an individual SME's location.

C: Information on counties in 2007-2012

\begin{tabular}{lcccccc}
\hline Variable & $\begin{array}{c}\text { Observa- } \\
\text { tions }\end{array}$ & Mean & Median & $\begin{array}{c}\text { Std. } \\
\text { deviation }\end{array}$ & Minimum & Maximum \\
\hline SALARY & 2274 & 0.8409 & 0.8110 & 0.1229 & 0.6090 & 1.8360 \\
ENTREPREN & 2274 & 0.1478 & 0.1390 & 0.0625 & 0.0170 & 0.3800 \\
UNEMPL & 2274 & 0.1040 & 0.1000 & 0.0278 & 0.0460 & 0.2210 \\
POPUL.DENS & 2274 & 0.3827 & 0.0898 & 0.6866 & 0.0193 & 4.1942 \\
\hline
\end{tabular}




\section{Empirical Results}

Tables 3 and 4 present the estimation results for different specifications of equation (1). In Table 3, we use a $2.5 \mathrm{~km}$ radius, whereas in Table 4 we use a $5 \mathrm{~km}$ radius to define a local banking market. First, we will concentrate on the testing of H1. As we can observe, the standing of SMEs affects cooperative banks' performance but not to the same degree in all studied aspects. The influence of SMEs' fundamentals is strongest in the case of profitability [specifications (1) to (3) and (8) to (10)]. Regardless of the method used to measure banks' profitability, the dependent variable is, as expected, positively influenced by firms' investment (AVG.INVEST), profitability (AVG.EBIT.S) and quick total asset turnover; these are also frequently viewed as signs of strong management (TAT) and profit growth (AVG.EBIT.GR). The findings are generally in line with Fredriksson and Moro's (2014) observation that more profitable SMEs may not be able to finance their growth by relying solely on their profits. Hence, they need the additional financing provided by banks that then benefit in terms of profitability. The impact of the variables AVG.INVEST, AVG.EBIT.S, $A V G_{-} T A T$ and $A V G$.EBIT.GR is insensitive to the changes in the radius used to delimit the local banking market. In contrast, the significance of the given SME's scale of operations ( $A V G . L N S$ ) depends on definition of the local banking market. The coefficients for this variable are all significantly different from zero when we apply the $2.5 \mathrm{~km}$ radius but statistically significant only once when we use the $5 \mathrm{~km}$ radius. The negative sign of the relevant coefficients contradicts Fredriksson and Moro's (2014) evidence that bigger firms generate greater profits for banks due to lower levels of risk and a greater operative need for banking services. Nevertheless, our outcome may be explained by the tendency of larger firms to use services of supra-local banks. With regard to asset quality, specifications (4) and (11) indicate that cooperative banks earn lower provisions when SMEs located near their branches are characterized by high profitability (AVG.EBIT.S) and quick asset turnover (AVG.TAT) and are able to invest ( $A V G . I N V E S T)$. In contrast, the growth of cooperative banks is generally independent of SMEs' fundamentals. This growth is influenced solely by SMEs' average scale of operations when we analyze the growth of deposits and total assets [specifications (5), (7), (12) and (14)]. In sum, we conclude that a strong financial standing of SMEs improves the performance of banks that operate in the same neighborhood. Therefore, we cannot reject $\mathrm{H} 1$ with regard to the financial results of cooperative banks. However, the standing of SMEs does not affect growth prospects for cooperative banks.

With regard to the bank-level control variables in Tables 3 and 4, poor cost control (OVERHEADS) results in lower profitability and is negatively connected, likely through the quality of management, with the pace of loans and asset growth. Larger cooperative banks $(L N A)$ grow faster but are characterized at the same time by lower profitability and less favorable asset quality. As expected, banks that rely more on fee-generating activities $(F E E S)$ are more profitable. There is also weak evidence that banks with a solid capital base (EQUITY) are able to attract more deposits and grow faster. Banks with already extensive credit portfolios (LOANS) report slower growth ratios for loans and relatively better asset quality. Somewhat surprisingly, a large proportion of loans is negatively and statistically significantly correlated with the net interest margin of banks. We conjecture that this regularity is linked to 


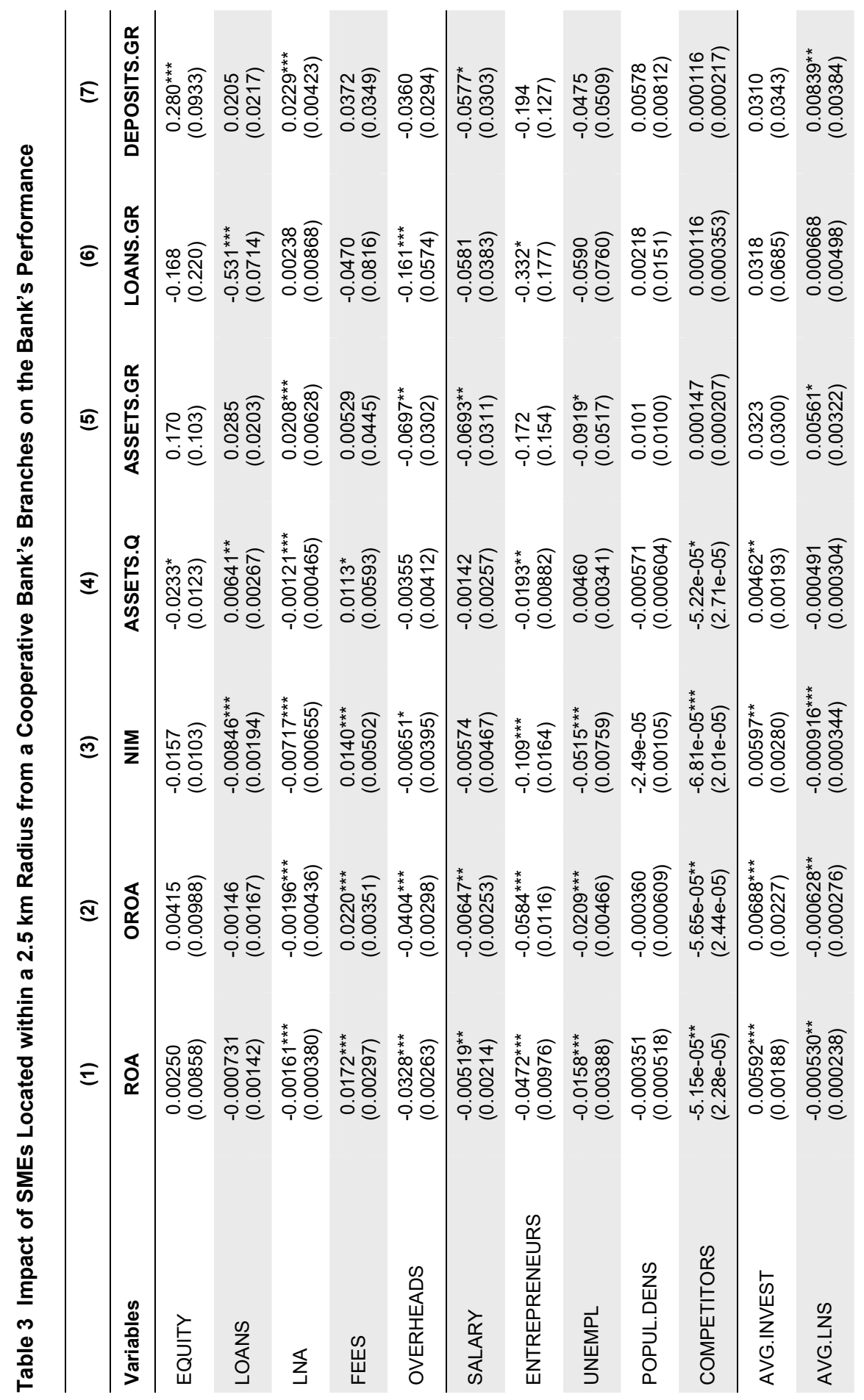




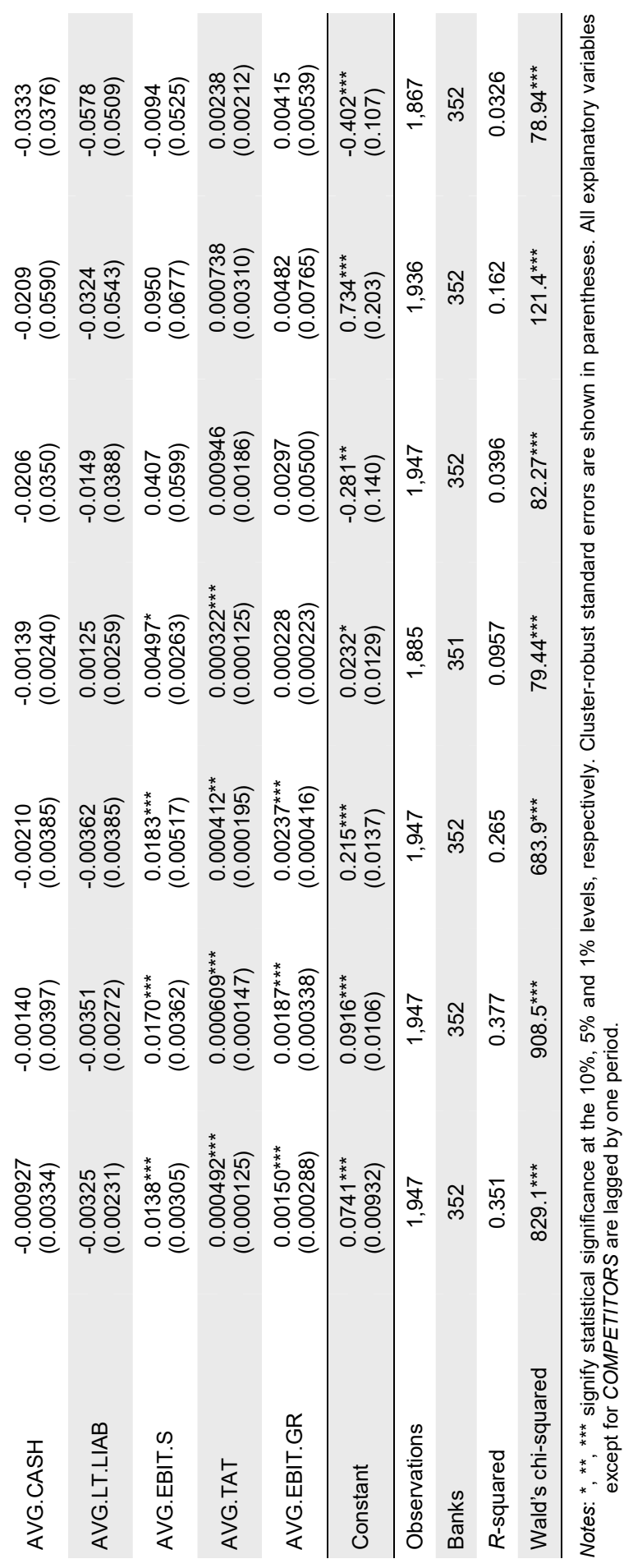




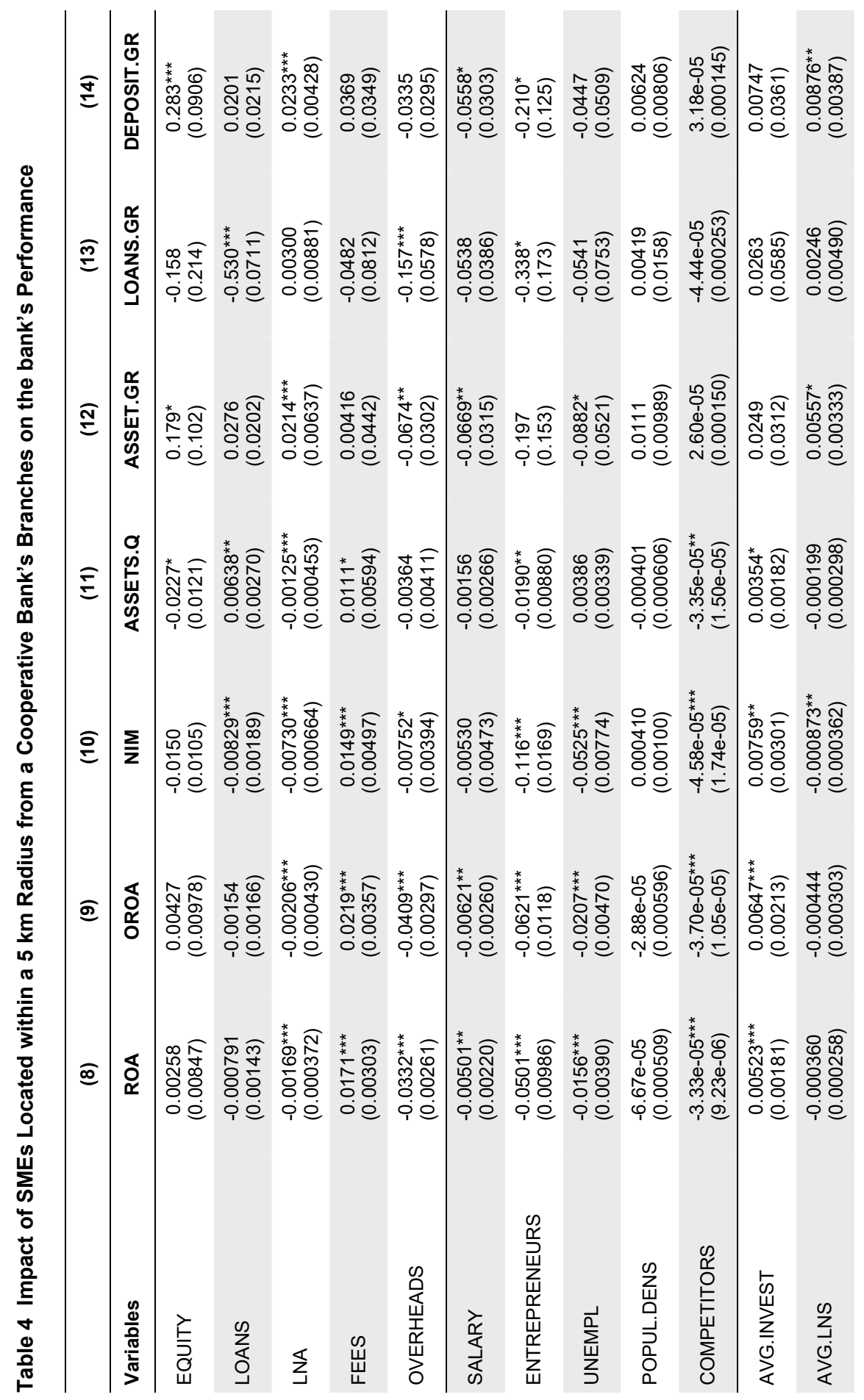




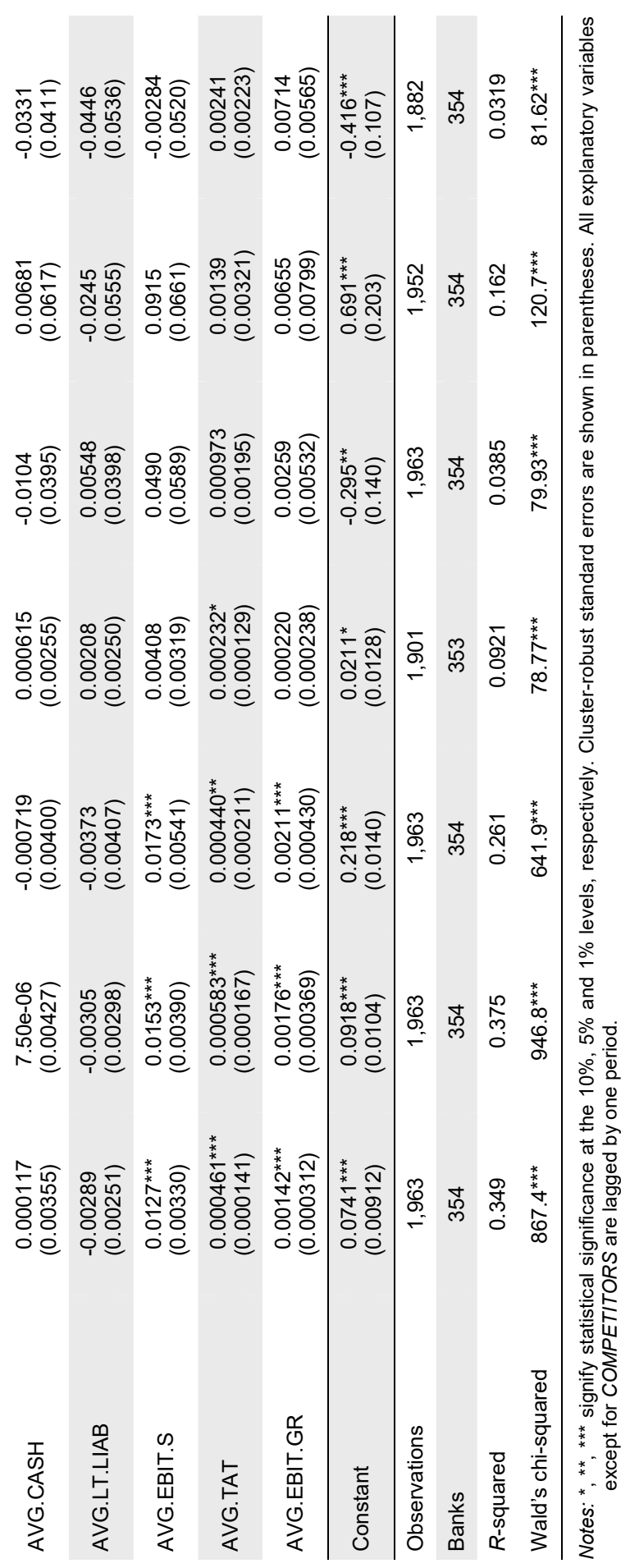


the fact that maintaining a large proportion of loans in assets may require a long-term policy of low interest margins.

Local economic conditions also importantly influence the performance of cooperative banks. As anticipated, a greater number of competitors and a more difficult situation in the labor market (UNEMPL) exert negative pressure on banks' profitability. Relatively modest wages $(S A L A R Y)$ also reduce banks' profits and inhibit banks' growth. Large proportions of self-employed persons (ENTREPREN) are significantly and negatively related to banks' profitability, loan growth and quality. We hypothesize that entrepreneurs are simply more likely to seek financial services outside local banking markets and that cooperative banks confronted with this attitude are obliged to grant relatively riskier loans. From the financial stability and policymaking perspectives, the negative and statistically significant coefficients obtained for the variable COMPETITORS in specifications (4) and (11) are particularly interesting. These coefficients imply that intense competition in local banking markets translates into lower-quality loan portfolios. The latter evidence corroborates the previous findings of Kozłowski (2015), who found evidence of downward competition with regard to credit standards when cooperative banks compete with credit unions.

The estimation results for the various versions of equation (2), contained in Tables 5 and 6 , reject $\mathrm{H} 2$. There is no evidence that the good standing of cooperative banks matters for SMEs' performance and prospects when they operate in the same neighborhood. None of the explanatory variables that illustrate cooperative banks' fundamentals (AVG.ROA, AVG.EQUITY and AVG.ASSETS.Q) robustly influences the dependent variables. This research outcome is insensitive to the definition of local banking markets. The hold-up problem signaled in the literature and discussed in Section 2 may constitute one of the explanations for this result.

With respect to variables that reflect local economic conditions, there is only weak evidence that UNEMPL impacts SMEs' profitability and sales growth in a stable manner. The positive coefficients calculated for this variable [specifications (15), (19), (21) and (24)] may suggest that a difficult situation in the local labor market favors cost reductions and, consequently, facilitates expansion of SMEs. In contrast, several firm-level control variables in Tables 5 and 6 are statistically significant. Our study reveals that [specifications (15), (16), (20) and (21)] larger SMEs (LNS) and, surprisingly, SMEs that possess higher cash stocks $(C A S H)$ are more profitable. The latter results may be explained by the fact that, due to data limitations, we are not able to control for the age of firms. In this situation, the variable $C A S H$ may reflect differences in firms' maturity because older entities tend to generate greater cash flows. SMEs' investments [specifications (18) and (23)] are positively affected by the scale of operations, cash holdings and profitability (EBIT.S) and negatively by the value of already existing fixed assets (FIXA). Sales growth [specifications (19) and (24)] is slower in more profitable firms, firms that invest more and firms that are characterized by quick total asset turnover (TAT). As anticipated, the need for longterm debt [specifications (17) and (22)] is, on the one hand, reduced by large scale operations, elevated cash holdings and high current profitability, and, on the other hand, augmented by investments and a large share of fixed assets in total assets. 
Table 5 Impact of Cooperative Banks Located within a 2.5 km Radius from an SME's Head Office on Its Performance

\begin{tabular}{|c|c|c|c|c|c|}
\hline & (15) & (16) & (17) & (18) & (19) \\
\hline Variables & EBIT.S & GROSS.PR.S & LT.LIAB & INVEST & SALES.GR \\
\hline LNS & $\begin{array}{c}0.0156^{* * *} \\
(0.00500)\end{array}$ & $\begin{array}{c}0.0111^{\star *} \\
(0.00467)\end{array}$ & $\begin{array}{l}0.00671^{* * *} \\
(0.00209)\end{array}$ & $\begin{array}{l}0.00988^{* * *} \\
(0.00247)\end{array}$ & $\begin{array}{l}-0.00451 \\
(0.00599)\end{array}$ \\
\hline TAT & $\begin{array}{l}-0.00218 \\
(0.00187)\end{array}$ & $\begin{array}{l}-0.000480 \\
(0.00204)\end{array}$ & $\begin{array}{l}-0.00863^{* * *} \\
(0.00144)\end{array}$ & $\begin{array}{c}0.00104 \\
(0.00191)\end{array}$ & $\begin{array}{l}-0.0227^{* * *} \\
(0.00410)\end{array}$ \\
\hline CASH & $\begin{array}{l}0.0749^{* * *} \\
(0.0226)\end{array}$ & $\begin{array}{l}0.0909^{* * *} \\
(0.0239)\end{array}$ & $\begin{array}{l}-0.0297^{* *} \\
(0.0128)\end{array}$ & $\begin{array}{l}0.0584^{* * *} \\
(0.0212)\end{array}$ & $\begin{array}{c}0.0387 \\
(0.0558)\end{array}$ \\
\hline INVEST & $\begin{array}{r}0.00997 \\
(0.0193)\end{array}$ & $\begin{array}{l}-0.0223 \\
(0.0213)\end{array}$ & $\begin{array}{l}0.0434^{\star * *} \\
(0.0123)\end{array}$ & & $\begin{array}{c}0.131^{* * *} \\
(0.0431)\end{array}$ \\
\hline FIXA & $\begin{array}{l}-0.0158 \\
(0.0218)\end{array}$ & $\begin{array}{l}-0.00709 \\
(0.0234)\end{array}$ & $\begin{array}{l}0.0804^{* * *} \\
(0.0147)\end{array}$ & $\begin{array}{l}-0.0921^{* * *} \\
(0.0153)\end{array}$ & $\begin{array}{l}-0.0230 \\
(0.0350)\end{array}$ \\
\hline EBIT.S & & & $\begin{array}{l}-0.0430^{* * *} \\
(0.0154)\end{array}$ & $\begin{array}{c}0.0467^{\star *} \\
(0.0216)\end{array}$ & $\begin{array}{l}-0.176^{\star *} \\
(0.0695)\end{array}$ \\
\hline AVG.ROA & $\begin{array}{c}0.306 \\
(0.368)\end{array}$ & $\begin{array}{c}0.564 \\
(0.347)\end{array}$ & $\begin{array}{l}-0.283 \\
(0.233)\end{array}$ & $\begin{array}{c}0.567 \\
(0.468)\end{array}$ & $\begin{array}{l}-2.665^{\star *} \\
(1.083)\end{array}$ \\
\hline AVG.EQUITY & $\begin{array}{l}-0.0842 \\
(0.0852)\end{array}$ & $\begin{array}{l}-0.0815 \\
(0.0808)\end{array}$ & $\begin{array}{l}-0.0439 \\
(0.0693)\end{array}$ & $\begin{array}{l}-0.0277 \\
(0.0796)\end{array}$ & $\begin{array}{c}0.190 \\
(0.157)\end{array}$ \\
\hline AVG.ASSETS.Q & $\begin{array}{l}-0.164 \\
(0.398)\end{array}$ & $\begin{array}{l}-0.180 \\
(0.307)\end{array}$ & $\begin{array}{c}0.213 \\
(0.223)\end{array}$ & $\begin{array}{c}0.186 \\
(0.451)\end{array}$ & $\begin{array}{r}1.846^{*} \\
(1.090)\end{array}$ \\
\hline SALARY & $\begin{array}{l}-0.0115 \\
(0.0406)\end{array}$ & $\begin{array}{l}-0.0142 \\
(0.0463)\end{array}$ & $\begin{array}{c}0.0339 \\
(0.0335)\end{array}$ & $\begin{array}{l}-0.0393 \\
(0.0370)\end{array}$ & $\begin{array}{c}0.0726 \\
(0.0774)\end{array}$ \\
\hline ENTREPRENEURS & $\begin{array}{c}0.129 \\
(0.203)\end{array}$ & $\begin{array}{c}0.305^{*} \\
(0.179)\end{array}$ & $\begin{array}{c}0.0695 \\
(0.127)\end{array}$ & $\begin{array}{l}-0.0403 \\
(0.138)\end{array}$ & $\begin{array}{l}-0.0954 \\
(0.300)\end{array}$ \\
\hline UNEMPL & $\begin{array}{c}0.117^{*} \\
(0.0713)\end{array}$ & $\begin{array}{c}0.0991 \\
(0.0746)\end{array}$ & $\begin{array}{c}0.00555 \\
(0.0571)\end{array}$ & $\begin{array}{l}-0.0107 \\
(0.0693)\end{array}$ & $\begin{array}{l}0.387^{* * *} \\
(0.135)\end{array}$ \\
\hline POPUL.DENS & $\begin{array}{l}0.0238^{* *} \\
(0.0112)\end{array}$ & $\begin{array}{c}0.0112 \\
(0.0169)\end{array}$ & $\begin{array}{l}-0.00223 \\
(0.00906)\end{array}$ & $\begin{array}{l}-0.00830 \\
(0.0121)\end{array}$ & $\begin{array}{c}0.0253 \\
(0.0253)\end{array}$ \\
\hline Constant & $\begin{array}{l}-0.162^{\star *} \\
(0.0701)\end{array}$ & $\begin{array}{l}-0.136^{*} \\
(0.0739)\end{array}$ & $\begin{array}{l}-0.0102 \\
(0.0459)\end{array}$ & $\begin{array}{l}-0.0237 \\
(0.0455)\end{array}$ & $\begin{array}{c}0.0629 \\
(0.106)\end{array}$ \\
\hline Observations & 4,474 & 4,466 & 4,475 & 5,164 & 4,466 \\
\hline Companies & 1,854 & 1,852 & 1,854 & 2,133 & 1,855 \\
\hline$R$-squared & 0.120 & 0.107 & 0.150 & 0.0181 & 0.0153 \\
\hline Wald's chi-squared & $194.9^{* * *}$ & $169.5^{\star \star \star}$ & $251.4^{\star * *}$ & $89.90^{* * *}$ & $84.93^{* * *}$ \\
\hline
\end{tabular}

Notes: ${ }^{*},{ }^{* *},{ }^{* * *}$ signify statistical significance at the $10 \%, 5 \%$ and $1 \%$ levels, respectively. Cluster-robust standard errors are shown in parentheses. Industry dummies are not reported, for brevity.

The re-estimation of all models with banks and firms fixed effects did not change the results of the testing of $\mathrm{H} 1$ and $\mathrm{H} 2$. Still, we may conclude that the standing of SMEs plays an important role in shaping cooperative banks' performance and that there is no evidence that a relation in the opposite direction exists. Because the main findings do not depend on the estimation procedure, for the sake of brevity, we do not report results when the fixed-effect estimator is used. However, the relevant research results are available from the authors upon request. 
Table 6 Impact of Cooperative Banks Located within a $5 \mathrm{~km}$ radius from an SME's Head Office on Its Performance

\begin{tabular}{|c|c|c|c|c|c|}
\hline & (20) & (21) & (22) & (23) & (24) \\
\hline Variables & EBIT.S & GROSS.PR.S & LT.LIAB & INVEST & SALES.GR \\
\hline LNS & $\begin{array}{c}0.0181^{* * *} \\
(0.00541)\end{array}$ & $\begin{array}{c}0.0140^{* * *} \\
(0.00522)\end{array}$ & $\begin{array}{l}0.00724^{* * *} \\
(0.00239)\end{array}$ & $\begin{array}{l}0.00938^{* * *} \\
(0.00257)\end{array}$ & $\begin{array}{l}-0.00412 \\
(0.00669)\end{array}$ \\
\hline TAT & $\begin{array}{l}-0.00115 \\
(0.00194)\end{array}$ & $\begin{array}{c}0.000204 \\
(0.00208)\end{array}$ & $\begin{array}{l}-0.00988^{* * *} \\
(0.00156)\end{array}$ & $\begin{array}{c}0.000856 \\
(0.00204)\end{array}$ & $\begin{array}{l}-0.0237^{* * *} \\
(0.00454)\end{array}$ \\
\hline $\mathrm{CASH}$ & $\begin{array}{l}0.0638^{* *} \\
(0.0249)\end{array}$ & $\begin{array}{l}0.0785^{\star \star *} \\
(0.0262)\end{array}$ & $\begin{array}{l}-0.0270^{*} \\
(0.0145)\end{array}$ & $\begin{array}{l}0.0608^{* * *} \\
(0.0236)\end{array}$ & $\begin{array}{c}0.0515 \\
(0.0656)\end{array}$ \\
\hline INVEST & $\begin{array}{l}-0.000462 \\
(0.0186)\end{array}$ & $\begin{array}{l}-0.00368 \\
(0.0196)\end{array}$ & $\begin{array}{l}0.0499^{* * *} \\
(0.0132)\end{array}$ & & $\begin{array}{l}0.156^{* * *} \\
(0.0469)\end{array}$ \\
\hline FIXA & $\begin{array}{l}-0.00296 \\
(0.0214)\end{array}$ & $\begin{array}{c}0.00169 \\
(0.0234)\end{array}$ & $\begin{array}{l}0.0621^{* * *} \\
(0.0155)\end{array}$ & $\begin{array}{l}-0.0730^{* * *} \\
(0.0149)\end{array}$ & $\begin{array}{l}-0.0146 \\
(0.0372)\end{array}$ \\
\hline EBIT.S & & & $\begin{array}{l}-0.0406^{* * *} \\
(0.0156)\end{array}$ & $\begin{array}{c}0.0343 \\
(0.0213)\end{array}$ & $\begin{array}{l}-0.180^{* *} \\
(0.0768)\end{array}$ \\
\hline AVG.ROA & $\begin{array}{c}0.402 \\
(0.412)\end{array}$ & $\begin{array}{r}0.702^{*} \\
(0.394)\end{array}$ & $\begin{array}{l}-0.158 \\
(0.257)\end{array}$ & $\begin{array}{c}0.554 \\
(0.532)\end{array}$ & $\begin{array}{l}-2.519^{* *} \\
(1.211)\end{array}$ \\
\hline AVG.EQUITY & $\begin{array}{l}-0.113 \\
(0.0901)\end{array}$ & $\begin{array}{l}-0.149^{*} \\
(0.0877)\end{array}$ & $\begin{array}{l}-0.0714 \\
(0.0737)\end{array}$ & $\begin{array}{l}-0.0397 \\
(0.0860)\end{array}$ & $\begin{array}{c}0.104 \\
(0.172)\end{array}$ \\
\hline AVG.ASSETS.Q & $\begin{array}{l}-0.484 \\
(0.462)\end{array}$ & $\begin{array}{l}-0.407 \\
(0.345)\end{array}$ & $\begin{array}{c}0.281 \\
(0.251)\end{array}$ & $\begin{array}{c}0.0925 \\
(0.549)\end{array}$ & $\begin{array}{c}1.176 \\
(1.346)\end{array}$ \\
\hline SALARY & $\begin{array}{l}-0.00912 \\
(0.0470)\end{array}$ & $\begin{array}{c}0.0124 \\
(0.0523)\end{array}$ & $\begin{array}{c}0.0380 \\
(0.0427)\end{array}$ & $\begin{array}{c}0.0153 \\
(0.0498)\end{array}$ & $\begin{array}{c}0.0932 \\
(0.102)\end{array}$ \\
\hline ENTREPRENEURS & $\begin{array}{l}-0.0140 \\
(0.232)\end{array}$ & $\begin{array}{c}0.0665 \\
(0.201)\end{array}$ & $\begin{array}{c}0.183 \\
(0.144)\end{array}$ & $\begin{array}{c}0.0174 \\
(0.152)\end{array}$ & $\begin{array}{l}-0.0894 \\
(0.355)\end{array}$ \\
\hline UNEMPL & $\begin{array}{c}0.121 \\
(0.0769)\end{array}$ & $\begin{array}{c}0.141^{*} \\
(0.0801)\end{array}$ & $\begin{array}{l}-0.00238 \\
(0.0564)\end{array}$ & $\begin{array}{l}-0.0362 \\
(0.0725)\end{array}$ & $\begin{array}{l}0.362^{* *} \\
(0.154)\end{array}$ \\
\hline POPUL.DENS & $\begin{array}{l}-0.00904 \\
(0.0197)\end{array}$ & $\begin{array}{l}-0.00782 \\
(0.0201)\end{array}$ & $\begin{array}{l}-0.0336^{\star * *} \\
(0.00984)\end{array}$ & $\begin{array}{l}-0.0103 \\
(0.00925)\end{array}$ & $\begin{array}{l}-0.0154 \\
(0.0252)\end{array}$ \\
\hline Constant & $\begin{array}{l}-0.183^{\star *} \\
(0.0818)\end{array}$ & $\begin{array}{l}-0.171^{* *} \\
(0.0800)\end{array}$ & $\begin{array}{l}-0.00694 \\
(0.0511)\end{array}$ & $\begin{array}{l}-0.0697 \\
(0.0526)\end{array}$ & $\begin{array}{c}0.0561 \\
(0.123)\end{array}$ \\
\hline Observations & 3,844 & 3,838 & 3,851 & 4,442 & 3,843 \\
\hline Companies & 1,570 & 1,569 & 1,572 & 1,812 & 1,575 \\
\hline$R$-squared & 0.132 & 0.126 & 0.153 & 0.0151 & 0.0160 \\
\hline Wald's chi-squared & $187.1^{* * *}$ & $157.0^{* * *}$ & $240.8^{* * *}$ & $88.29^{* * *}$ & $79.92^{* * *}$ \\
\hline
\end{tabular}

Notes: ${ }^{*},{ }^{* *},{ }^{* *}$ signify statistical significance at the $10 \%, 5 \%$ and $1 \%$ levels, respectively. Cluster-robust standard errors are shown in parentheses. Industry dummies are not reported, for brevity.

The results reported so far concern the entire sample period. In Tables 7-10, we check whether our results are sensitive to macroeconomic tendencies. For the sake of brevity, in those tables we report only the results directly related to $\mathrm{H} 3$ testing. Tables 7 and 8 show that the positive impact of the standing of SMEs on cooperative banks' profitability is unexpectedly weaker during difficult economic times. The coefficients estimated for the interaction term $A V G \_$EBIT.S x DOWNTURN are negative and significant in four out of six specifications explaining banks' profitability. Interestingly, both tables indicate that cooperation with relatively large 


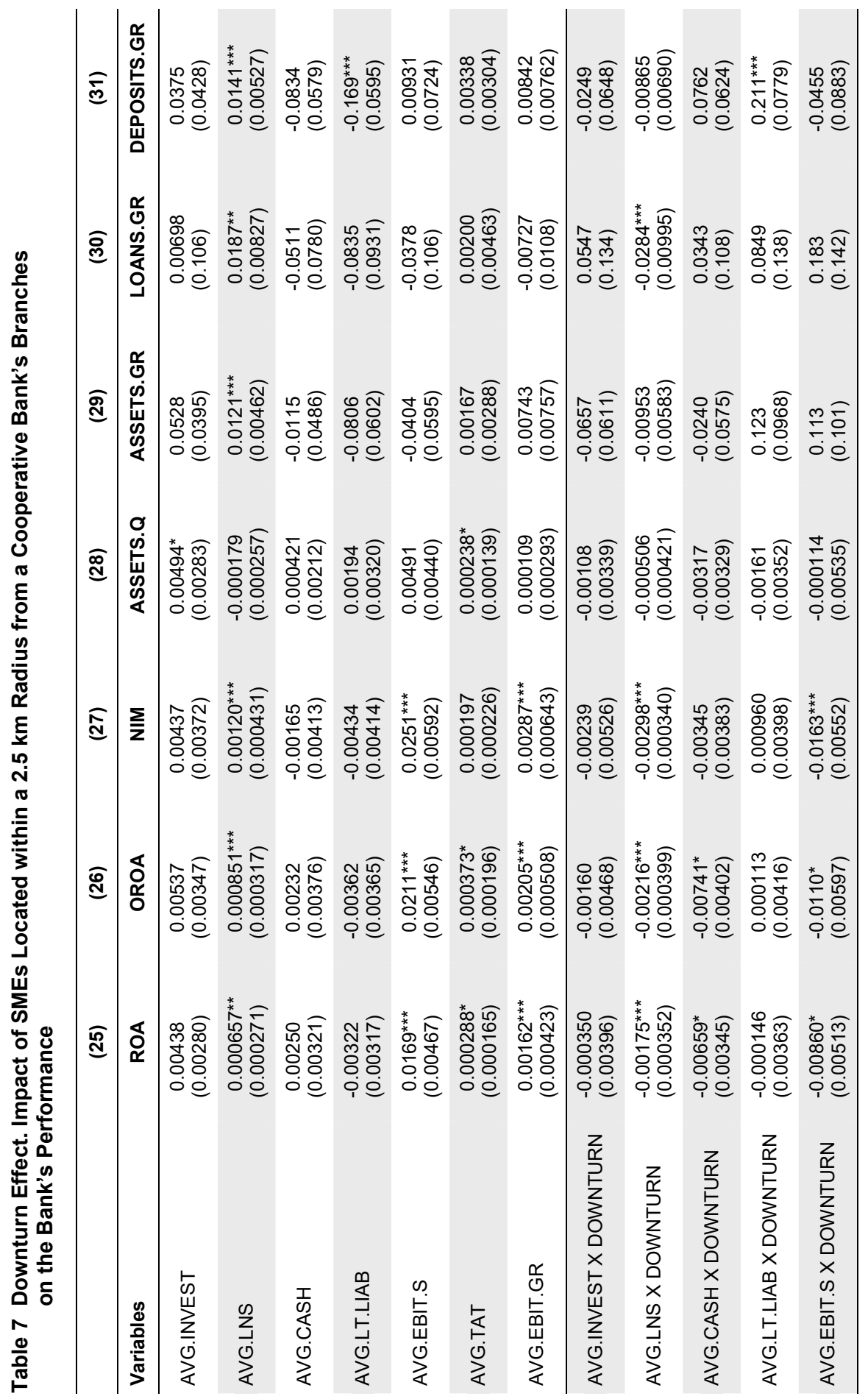




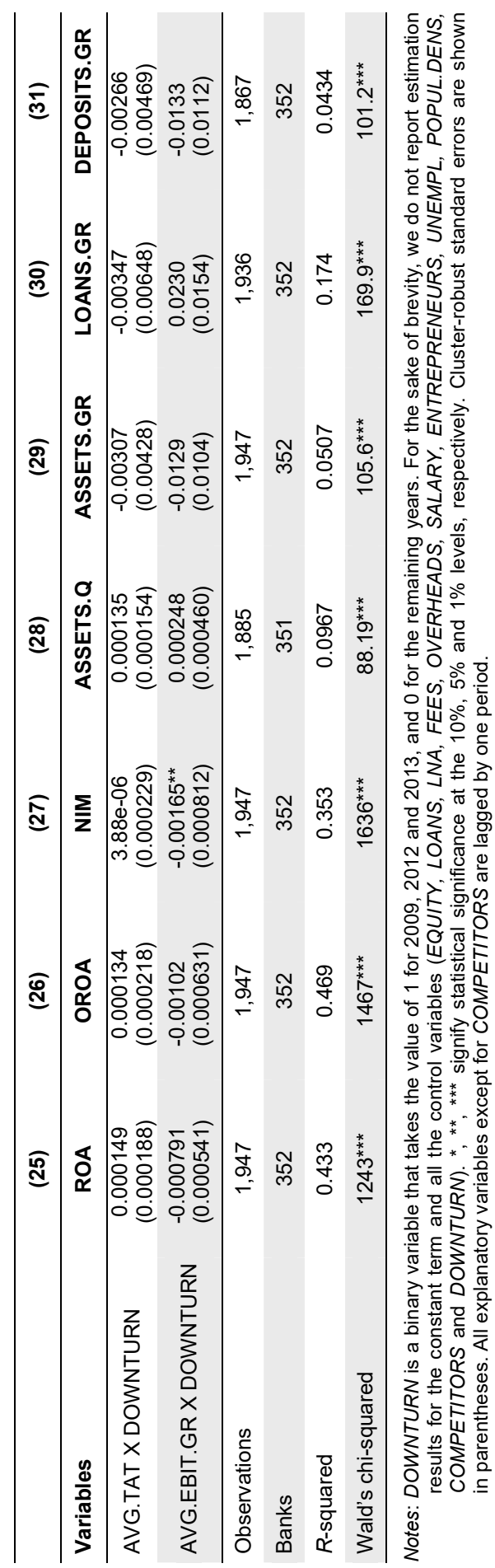




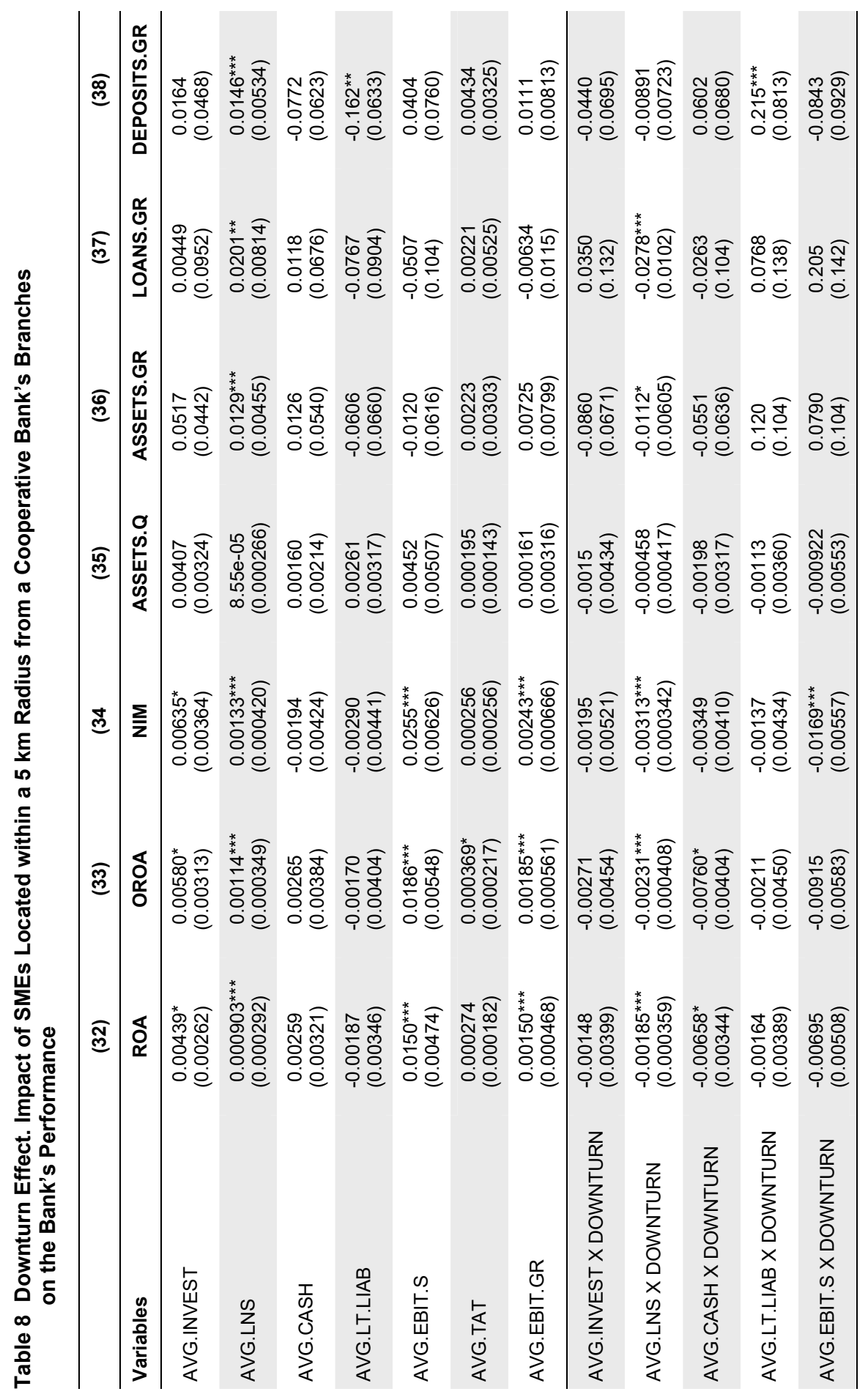




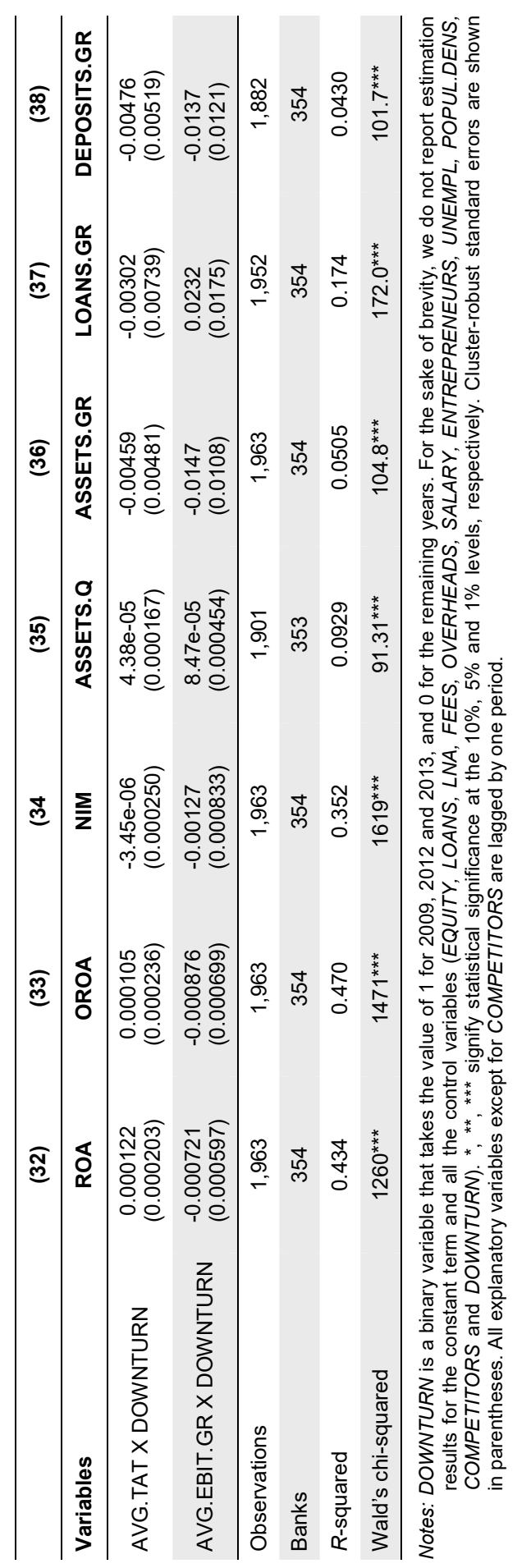


Table 9 Downturn Effect. Impact of Cooperative Banks located within a $2.5 \mathrm{~km}$ Radius from an SME's Head Office on Its Performance

\begin{tabular}{lccccc}
\hline & $\mathbf{( 3 9 )}$ & $\mathbf{( 4 0 )}$ & $\mathbf{( 4 1 )}$ & $\mathbf{( 4 2 )}$ & $\mathbf{( 4 3 )}$ \\
\hline Variables & EBIT.S & GROSS.PR.S & LT.LIAB & INVEST & SALES.GR \\
\hline AVG.ROA & 0.0358 & 0.0432 & -0.565 & 0.612 & -0.816 \\
& $(0.537)$ & $(0.521)$ & $(0.391)$ & $(0.668)$ & $(1.594)$ \\
AVG.EQUITY & -0.0540 & -0.0459 & -0.0218 & -0.0288 & 0.00797 \\
& $(0.0974)$ & $(0.0922)$ & $(0.0804)$ & $(0.112)$ & $(0.207)$ \\
AVG.ASSETS.Q & -0.280 & 0.229 & 0.0560 & 0.327 & 1.017 \\
& $(0.542)$ & $(0.372)$ & $(0.262)$ & $(0.572)$ & $(1.193)$ \\
\hline AVG.ROA x DOWNTURN & 0.958 & $1.516^{* *}$ & 0.0520 & 0.784 & 1.786 \\
& $(0.784)$ & $(0.749)$ & $(0.472)$ & $(0.886)$ & $(2.029)$ \\
AVG.EQUITY x DOWNTURN & -0.116 & -0.130 & 0.00285 & -0.0748 & -0.113 \\
& $(0.0820)$ & $(0.0820)$ & $(0.0726)$ & $(0.136)$ & $(0.258)$ \\
AVG.ASSETS.Q x & 0.130 & -1.390 & 0.842 & -0.926 & -1.297 \\
x DOWNTURN & $(1.018)$ & $(0.866)$ & $(0.572)$ & $(1.010)$ & $(2.153)$ \\
\hline Observations & 4,474 & 4,466 & 4,475 & 5,164 & 4,466 \\
Companies & 1,854 & 1,852 & 1,854 & 2,133 & 1,855 \\
\hline R-squared & 0.120 & 0.108 & 0.150 & 0.0188 & 0.0274 \\
Wald's chi-Squared & $214.7^{* * *}$ & $177.2^{* * *}$ & $258.4^{* * *}$ & $101.3^{* * *}$ & $145.4^{* * *}$ \\
\hline
\end{tabular}

Notes: DOWNTURN is a binary variable that takes the value of 1 for 2009, 2012 and 2013, and 0 for the remaining years. For the sake of brevity, we do not report estimation results for the constant term, industry dummies and all the control variables (LNS, TAT, CASH, INVEST, FIXA, EBIT.S, SALARY, ENTREPRENEURS, UNEMPL, POPUL.DENS and DOWNTURN).*, **, *** signify statistical significance at the $10 \%, 5 \%$ and $1 \%$ levels, respectively. Cluster-robust standard errors are shown in parentheses.

SMEs and SMEs with elevated cash holdings during times of economic hardship negatively affects cooperative banks' financial results. The former empirical pattern may be caused by the fact that firms' sensitivity to the business cycle increases as the scale of operations increases. The latter probably stems from the negative relationship between loan demand and cash holdings.

The impact of an economic downturn on the relationship between cooperative banks' financial health and SMEs' performance, according to Tables 9 and 10, depends on the radius used to delimit a local market. When we apply a $2.5 \mathrm{~km}$ radius, the banks' fundamentals remain, generally speaking, irrelevant for SMEs' financial standing and traits. However, when we switch to a $5 \mathrm{~km}$ radius, we obtain some evidence that during an economic slowdown banks' fundamentals do matter for SMEs' profitability measured on the level of gross income [specification (45)]. Namely, the SMEs' profitability is negatively influenced by a conservative attitude of cooperative banks expressed in their high equity levels and asset quality. In contrast, the $R O A$ variable is positively and significantly correlated with SMEs' profit-ability in the same regressions.

In sum, our research outcome also rejects H3. There is no evidence that the positive feedback between cooperative banks' financial health and SMEs' performance strengthens during economic downturns. On the contrary, we noticed that during the economic slowdown the positive impact of SME's standing on co- 
Table 10 Downturn Effect. Impact of Cooperative Banks Located within a $\mathbf{5}$ km Radius from an SME's Head Office on Its Performance

\begin{tabular}{lccccc}
\hline & $\mathbf{( 4 4 )}$ & $\mathbf{( 4 5 )}$ & $\mathbf{( 4 6 )}$ & $\mathbf{( 4 7 )}$ & $\mathbf{( 4 8 )}$ \\
\hline Variables & EBIT.S & GROSS.PR.S & LT.LIAB & INVEST & SALES.GR \\
\hline AVG.ROA & -0.000764 & 0.123 & -0.630 & 0.609 & -0.873 \\
& $(0.592)$ & $(0.548)$ & $(0.424)$ & $(0.720)$ & $(1.795)$ \\
AVG.EQUITY & -0.0537 & -0.0989 & -0.0224 & -0.0498 & -0.0135 \\
& $(0.108)$ & $(0.102)$ & $(0.0849)$ & $(0.121)$ & $(0.228)$ \\
AVG.ASSETS.Q & -0.333 & 0.201 & 0.172 & 0.0579 & 0.444 \\
& $(0.642)$ & $(0.417)$ & $(0.305)$ & $(0.678)$ & $(1.673)$ \\
\hline AVG.ROA x DOWNTURN & 1.224 & $1.726^{* *}$ & 0.275 & 0.743 & 2.664 \\
& $(0.873)$ & $(0.801)$ & $(0.504)$ & $(0.978)$ & $(2.251)$ \\
AVG.EQUITY X DOWNTURN & $-0.174^{*}$ & $-0.170^{*}$ & -0.0414 & -0.0545 & -0.305 \\
AVG.ASSETS.Q x & $(0.0906)$ & $(0.0883)$ & $(0.0743)$ & $(0.150)$ & $(0.279)$ \\
X DOWNTURN & -0.652 & $-1.979^{* *}$ & 0.851 & -0.504 & -2.292 \\
\hline Observations & $(1.074)$ & $(0.913)$ & $(0.584)$ & $(1.109)$ & $(2.494)$ \\
\hline Companies & 3,844 & 3,838 & 3,851 & 4,442 & 3,843 \\
R-squared & 1,570 & 1,569 & 1,572 & 1,812 & 1,575 \\
Wald's chi-squared & 0.132 & 0.126 & 0.154 & 0.0157 & 0.0285 \\
\hline
\end{tabular}

Notes: DOWNTURN is a binary variable that takes the value of 1 for 2009, 2012 and 2013, and 0 for the remaining years. For the sake of brevity, we do not report estimation results for the constant term, industry dummies and all the control variables (LNS, TAT, CASH, INVEST, FIXA, EBIT.S, SALARY, ENTREPRENEURS, UNEMPL, POPUL.DENS and DOWNTURN).*, **, *** signify statistical significance at the $10 \%, 5 \%$ and $1 \%$ levels, respectively. Cluster-robust standard errors are shown in parentheses

operative banks' performance weakened to a certain degree. With regard to the influence of cooperative banks' financial health on SMEs' performance during an economic downturn, our evidence is inconclusive.

\section{Concluding Remarks}

This paper constitutes a part of a broader research project that pertains to the significance of local structures of the financial system for SMEs' prospects. In an accompanying paper (Hasan et al., 2015), we established that the strong position of cooperative banks facilitates access to bank financing, lowers financial costs and boosts growth for SMEs. However, we found that only local banking markets dominated by supra-local, domestic or foreign banks exert pressure on SMEs to increase efficiency. By testing the interactions between the financial health of cooperative banks and SMEs' performance, we are moving a step further in our analysis. Namely, on the one hand, we determine not only whether the presence of local banks but also whether their strong financial health is beneficial for SMEs and, on the other hand, whether SMEs' favorable condition positively influences local banks' performance. The empirical results are partially surprising. First, we unexpectedly find that there is no evidence that strong financial positions of cooperative banks boost SMEs' performance. Second, as in Fredriksson and Moro (2014), we show that a strong standing of SMEs improves local banks' profitability 
and asset quality. Therefore, when we examine Figure 1, we conclude that solely the existence of the relation represented by the upper arrow was empirically supported in Poland. Third, the positive feedback between SMEs' performance and cooperative banks' financial health does not strengthen during an economic downturn.

Our study also leads to several detailed results concerning the determinants of cooperative banks and SMEs' performance. Among these results, we believe one is particularly interesting. As in Kozłowski (2015), we find certain evidence that strong competition in local financial markets may be undesirable from the financial stability perspective. Our empirical evidence documents that asset quality in cooperative banks worsens when they are confronted with a large number of local competitors.

Despite the fact that our results are based only on Polish data, we believe that they have a broader appeal. We believe that the research outcomes are also relevant for neighboring Central European economies that are characterized by a similar economic history, economic structures and institutions. In contrast, the significance of our findings for the so-called old-members of the EU is at best limited due to persistent differences in economic and institutional developments 25 years after transformation. 


\section{REFERENCES}

Abor JY, Agbloyor EK, Kuipo R (2014): Bank finance and export activities of Small and Medium Enterprises. Review of Development Finance, 4(2):97-103.

Agarwal S, Hauswald R (2010): Distance and private Information in lending. Review of Financial Studies, 23:2757-88.

Behr P, Norden L, Noth F (2013): Financial constraints of private firms and bank lending behavior. Journal of Banking and Finance, 37(9):3472-3485.

Berger AN, Miller NH, Petersen MA, Rajan RG, Stein JC (2005): Does function follow organizational form? Evidence from the lending practices of large and small banks. Journal of Financial Economics, 76:237-69.

Berger AN, Cerqueiro G, Penas MF (2015): Market size structure and small business lending: Are crisis times different from normal times? Review of Finance, 19(5):1965-95.

Boot AWA (2000): Relationship banking: What do we know? Journal of Fiancial Intermediation, 9:7-25

DeYoung R (2002): New bank start-ups: Entrepreneurs funding other entrepreneurs. Journal of Entrepreneurial Finance and Business Ventures, 7(3):61-76.

Fredriksson A, Moro A (2014): Bank-SMEs relationship and banks' risk adjusted profitability. Journal of Banking and Finance, 41:67-77.

Haas R de, Ferreira D, Taci A (2010): What determines the composition of banks' loan portfolios? Evidence from transition countries. Journal of Banking and Finance, 34:388-98.

Höwer D (2016): The role of bank relationships when firms are financially distressed. Journal of Banking and Finance, 65:59-75

Hasan I, Jackowicz K, Kowalewski O, Kozłowski Ł (2015): Do local banking market structures matter for SME financing and performance? New evidence from an emerging economy. Working paper. Available at SSRN: http://dx.doi.org/10.2139/ssrn.2727941.

Kozłowski Ł (2016): Synergy or downward competition? Interactions between small credit institutions in local markets. Finance Research Letters, 16:66-74.

Peek J, Rosengren ES (2005): Perverse incentives and the misallocation of credit in Japan. American Economic Review, 95:1144-1166.

Petersen MA, Rajan RG (1994): The benefits of firm-creditor relationships: Evidence from small business data. Journal of Finance, 49(1):3-37.

Presbitero AF, Udell GF, Zazzaro A (2014): The home bias and the credit crunch: A regional perspective. Journal of Money, Credit and Banking, 46(1):53-85.

Ryan RM, O'Toole CM, McCann F (2014): Does bank market power affect SME financing constraints? Journal of Banking and Finance, 49:495-505.

Uchida H, Udell GF, Watanabe W (2008): Bank size and lending relationships in Japan. Journal of the Japanese and International Economies, 22:242-67.

Zhang X, Song Z, Zhong Z (2016): Does "small bank advantage" really exist? Evidence from China. International Review of Economics and Finance, 42:368-384. 